\title{
Sweet Corn, Explored as a Companion Plant, Mitigates Sucking Insects in Industrial Tomato Plants, Pre-flowering Stage
}

\author{
Ana Paula Silva ${ }^{1}$, Bruno Barboza dos Santos ${ }^{1}$, Alírio Felipe Alves Netto ${ }^{2}$, Cide Moreira da Silva ${ }^{1}$, \\ Carmen Rosa da Silva Curvêlo ${ }^{1}$, Luiz Leonardo Ferreira ${ }^{3}$, José Magno Queiroz Luz ${ }^{4}$ \\ $\&$ Alexandre Igor Azevedo Pereira ${ }^{1}$ \\ ${ }^{1}$ Instituto Federal Goiano, Campus Urutaí, Urutaí, Goiás, Brazil \\ ${ }^{2}$ Instituto Federal Goiano, Campus Morrinhos, Morrinhos, Goiás, Brazil \\ ${ }^{3}$ Centro Universitário de Mineiros, Mineiros, Goiás, Brazil \\ ${ }^{4}$ Universidade Federal de Uberlândia, Campus Umuarama, Uberlândia, Minas Gerais, Brazil \\ Correspondence: Alexandre Igor Azevedo Pereira, Instituto Federal Goiano, Campus Urutaí, Rodovia Geraldo \\ Silva Nascimento, Km 2.5, Fazenda Palmital, CEP: 75.790-000, Urutaí, Goiás, Brazil. Tel: 55-64-992-874-821. \\ E-mail: aiapereira@yahoo.com.br
}

Received: July 14, 2018

doi:10.5539/jas.v10n11p451
Accepted: August 29, $2018 \quad$ Online Published: October 15, 2018

URL: https://doi.org/10.5539/jas.v10n11p451

\begin{abstract}
Plant diversification mitigates colonization by herbivorous insects in agricultural systems. Tomato and sweet corn generate raw material, for industrial processing, with outstanding production in Goiás state, Brazil. Yet, little is known about the potential of sweet corn as a companion plant for sucking insects, and natural enemies, in tomato plants. We collected pests and natural enemies in tomato (pre-flowering stage) plants under three treatments: isolated tomato plants (T1), tomato plants with sweet corn in the border (T2), and tomato plants with polyculture (garlic, lettuce, and squash) in the border (T3). The insects were collected by yellow sticky traps. Dalbulus maidis (29.52\%), Frankliniella schultzei (23.90\%), F. occidentalis (18.72\%) and Myzus persicae (15.20\%) corresponded to $87.34 \%$ of the total insects collected. Tomato plants cultivated with sweet corn on the border had lower infestation of the thrips, F. schultzei as well as the aphid M. persicae. The number of D. maidis and F. occidentalis adults did not change according to the treatments. Diabrotica speciosa and Astylus variegatus were more collected in tomato plants with adjacent sweet corn. Predators and parasitoids represented only $6.62 \%$ of the total abundance. Cycloneda sanguinea and parasitoids were more collected in tomato plants with polyculture (T3). Tomato with sweet corn or polyculture favored the abundance of the predator Sphaerophoria scripta. Considerations around the control of insect pests and the sustenance of natural enemies in tomato plants, with sweet corn acting as a companion plant, in the pre-flowering stage of that Solanaceae, are demonstrated.
\end{abstract}

Keywords: diversification, Solanum lycopersicum, Zea mays, pests, natural enemies

\section{Introduction}

Production of tomatoes for processing sauces, extracts, juices and other by-products has a striking spot in Goiás state, Brazil (Carvalho \& Pagliuca, 2007). This increase was boosted in the last decades due to the installation of agroindustries that benefit this raw material. Nevertheless, the average Brazilian yield (90 ton ha ${ }^{-1}$ ) (IBGE, 2015) is still a lot more depressed than that obtained in other countries, as in USA (e.g. California state: 200 ton ha ${ }^{-1}$ ). The infestation of insects and tropical diseases, besides privation of technologies to manage crops, are genuine obstacles to industrial tomato production in Brazil. This scenario justifies high tomato rates of imports by processing industries to satisfy the growing demand (Silva et al., 2003).

The promise of buying and selling with agroindustries is an alternative for farmers seeking economic advantages, in order to remedy limitations in achieving high yield levels. The use of central pivot irrigation-type, a well-defined agricultural calendar and the constant demand for raw materials encourage a more diversified agricultural exploration. Therefore, three to four different harvests per annual agricultural calendar may occur, involving different agricultural plant species. A classic example is the cultivation (in different time windows) of tomato and sweet corn, both for industrial processing. More improved versions of this system include the 
cultivation, in the same time window, of tomato and sweet corn. With this, the farmer is able to stabilize the supply of raw material to the agroindustry, which becomes an economically important practice.

Tomato and sweet corn production in the same area favor the physical and chemical attributes of the cultivated soil (Njuguna et al., 2015). But, the efficiency of sweet corn to serve as a companion plant against herbivorous insects attacking tomato is still little investigated. Environmental complexity may indirectly interfere with pest insect colonization through resource dilution, deterrence, allelopathic effects, natural enemies conservation or, directly, with the physical effects of plant architecture (Ratnadass et al., 2011). Companion plants, intercropping, plant-baiting, and repellent plants are denominations for plant species that play a distinguished role in serving to exclude chewing insects and vectors of viruses (Carvalho \& Michereff Filho, 2009; Degree \& Somalia, 2014; Rhino et al., 2014). Some works have guided out the role of Zea mays (Poaceae) as a companion plant in the containment of fruit borers in tomato plants (Degri \& Somalia, 2014; Rhino et al., 2014).

The current production systems come from increasingly integrating sweet corn and industrial tomato plants in the same agricultural landscape. Nevertheless, the benefits (or not) of this arrangement in terms of containment virus-transmitting insects, and beyond other ecological niches (such as natural enemies) are even obscure. Sweet corn having the function as a companion plant to industrial tomato plants, helping to mitigate the incidence of tomato virus vectors, was our tested hypothesis. In addition, the population of natural enemies was also sampled to observe how agricultural landscape can affect this trophic level. The aim of this study was to assess the presence of herbivores and natural enemies in industrial tomato plants (pre-flowering stage), through yellow sticky traps, cultivated under different arrangements of agricultural landscape diversification.

\section{Methods}

Three industrial tomatoes (Solanum lycopersicum L, Solanaceae) production areas, located in the southeastern Goiás state, Brazil were selected. Each of the agricultural areas had their own agricultural landscape. In area 1 (Pires do Rio) there were 60 ha of isolated tomato, with no cultivated agricultural plants in the borders. In area 2 (Orizona) a total of 80 ha was divided, half-way, with tomato and sweet corn cultivation. Then sweet corn was considered the border plant in area 2. In area 3 (Urutaí) 10 hectares were cultivated with industrial tomatoes and, in the border, 2 ha of the area were kept with polyculture comprised of garlic, lettuce and squash plants. For convenience, we call the three areas as treatments $\mathrm{T} 1, \mathrm{~T} 2$, and $\mathrm{T} 3$, respectively. The distances between the treatments were $50 \mathrm{~km}$ (T1 to T2), $70 \mathrm{~km}$ (T1 to T3) and $30 \mathrm{~km}$ (T2 to T3).

Soil preparation in all three treatments was accomplished through mechanized sorting and subsequent acidity correction based on soil analysis. Fertilization of tomato plants was carried out in planting grooves and soon after the opening of the pits at the time of transplanting. Seedlings of Heinz 9553 cultivar (H. J. Heinz Company) were grown from a certified nursery in the municipality of Nerópolis, Goiás state, Brazil. This cultivar has 110 to 120 days of maturation and great adaptability to the regional field conditions. Fruit maturity index equal to 2 , degrees Brix of 4.9 to 5.1, resistance to Verticillium race 1, resistance to Fusarium race 1 and race 2, resistance to nematodes and resistance to Stemphyllium spp.

The recommended doses of nitrogen, phosphorus, calcium, magnesium, and potassium, as well as micronutrients (for foundation fertilization and cover) followed specific technical recommendations from Heinz company. The adopted spacing was $0.30 \mathrm{~m}$ between plants and between rows simultaneously two spacings were used: $0.60 \mathrm{~m}$ and $1.20 \mathrm{~m}$. This spacing is recommended in order to facilitate the mechanical harvesting of mature tomatoes.

Sweet corn used only in T2 was the Tropical Plus ${ }^{\circledR}$ hybrid (Syngenta Seeds Ltda). Sowing was performed 10 days before transplanting the tomato with a spacing of $80 \times 25 \mathrm{~cm}$, with three seeds per $2 \mathrm{~cm}$ deep pits. For T3 where there was the presence of polyculture in the border, the garlic (Ito cultivar) was used. Garlic bulbs (from Fazenda Paineiras, Campo Alegre de Goiás, Goiás) were stored for 40 days in a cold room at a temperature between $2-4^{\circ} \mathrm{C}$ and relative humidity of $50-60 \%$. Garlic planting occurred, manually, soon after the beds were ready. Double lines $(30 \mathrm{~cm} \times 10 \mathrm{~cm} \times 10 \mathrm{~cm})$ were used for garlic planting, by a mechanized finisher. The cultivation of the green-leaf lettuce (Brida cultivar) (Hortec Tecnologia de Sementes Ltda) followed spacing of $25 \mathrm{~cm} \times 25 \mathrm{~cm}$. Seedlings transplanted were previously kept for 18 days in a nursery. The squash (Italian type) (Feltrin Sementes) was cultivated by manually direct sowing and kept in the field under spacing of $100 \mathrm{~cm} \times 150$ $\mathrm{cm}$. At the time of assembly of the yellow sticky traps in T3, garlic and lettuce had 40 and 25 days of germination, respectively, while the squash, during the flowering phase (about 35 days).

Yellow-colored sticky traps $(15 \mathrm{~cm}$ high $\times 10 \mathrm{~cm}$ width) recommended for monitoring insect in tomatoes (Yen et al. 2013) were only installed inside the crop with industrial tomato plants. In each of three treatments, four traps were installed with a covered area a part each one of $33 \mathrm{~m}^{2}$, totaling an area $132 \mathrm{~m}^{2}$ with traps, for each treatment. The principle of collecting the yellow sticky traps resides in the fact that yellow-attracted insects are stuck, 
therefore, inspections of traps provide reliable data on the presence of insect populations (Baideng et al., 2017). The adhesive traps were installed immediately above the upper third tomato plants. The maintenance of traps in the field for 15 days occurred according to technical recommendation (Promip ${ }^{\circledR}$, Limeira, SP, Brasil). In all plots, where the yellow sticky traps were installed, there was no application of insecticides or herbicides until the $15^{\text {th }}$ day of field trapping. The experiment was carried out during April, 2017.

All captured insects were counted and identified in the laboratory with the help of a magnifying glass $(\times 50)$. Taxonomic keys, photographic guides and text references and images over the internet were used to separate collected insects into species and ecological niches. Voucher species were deposited at the entomology laboratory of IF Goiano, Urutaí Campus.

A Monte Carlo analysis was processed 10,000 times to assess whether the amount of each insect species collected between treatments could be explained by the chance of capture. Monte Carlo analysis provides simulated (a posteriori) values from the original number of captured insects (Gotelli \& Ellison, 2011). This analysis has been used to test scientific hypotheses (Wallerberger \& Gull, 2017), such as those related to insect populations in different areas (Barbosa et al.2005). Thus, if the actual number of captured insects (without Monte Carlo simulation processing) is significantly higher, then the simulated data are significantly different $(\alpha=0.05)$. The null hypothesis of the test was the pattern in the real data is not different from that with the simulated samples, for each species of insect captured, between the different treatments. The test yields an appropriate $P$ value for comparisons between treatments. The differences in the amount of each group of insects collected per treatment were statistically diagnosed through $P$ value obtained. In addition, the means of insects collected by trap, between treatments, were compared with Duncan test at 5\% probability level. The abundance values of the species and groups collected were described by percentage. The Monte Carlo analyzes were performed using the software@Risk (@RISK Technologies Inc.) (Pallisade, 2002) adapted for Excel (Microsoft Office package), while the figures were elaborated by SigmaPlot ${ }^{\circledR}$ version 11 (Systat Software Inc).

\section{Results and Discussion}

A total of 2,334 insects was collected during 15 days, with an average of 194.5 insects collected by each yellow sticky trap. The use of adhesive traps is important to access the population of insects in tomato plants. Our number of insects collected was much lower than that reported in other studies (see Baideng et al., 2017). This may have occurred due to the sampling effort that only concentrated on the tomato pre-flowering stage. The evaluation of companion plants for tomato, such as corn, for longer periods (for example, until tomato fruiting), is important, due to the occurrence of fruit borers, and because these are polyphagous, such as Noctuidae caterpillars (Degri \& Samaila, 2014). However, tomato pre-flowering stage has been referred to as very susceptible to the presence of sucking insect vectors of virus that may entirely compromise tomato development and production (Lima et al., 2016). This higher phenological susceptibility to insects transmitting viruses justifies the focus on the pre-flowering phase and highlights the importance of the present study.

The corn leafhopper, Dalbulus maidis (Hemiptera: Cicadellidae), was the most abundant insect collected by yellow sticky traps, followed by Frankliniella schultzei and F. occidentalis (Thysanoptera: Thripidae) thrips, and the aphid Myzus persicae (Hemiptera: Aphididae) (Figure 1). These four sucking insects corresponded to 87.34\% of the total insect abundance. There is no record of D. maidis transmitting virus in tomato plants in Brazil. This suggests that the presence of this insect was due to the own efficiency of the trap. However, corn crops have been infested with pathogens transmitted by D. maidis in Brazil (Oliveira et al., 2007). Therefore, the role of yellow sticky traps, which follows the Integrated Pest Management philosophy, in corn plantations for monitoring and collecting this insect can be promising and needs to be better explored. Thrips and aphids, on the other hand, are insect vectors of viruses that occur in tomato plants in Brazil (Miranda et al., 1998) and therefore considered as key pests. The present study confirms that sucking insects are the first to colonize tomato in the pre-flowering phase, as also reported by Moura et al. (2014). This indicates that preventive measures to control these virus transmitters should be recommended, soon after transplanting of tomato seedlings to the field. 


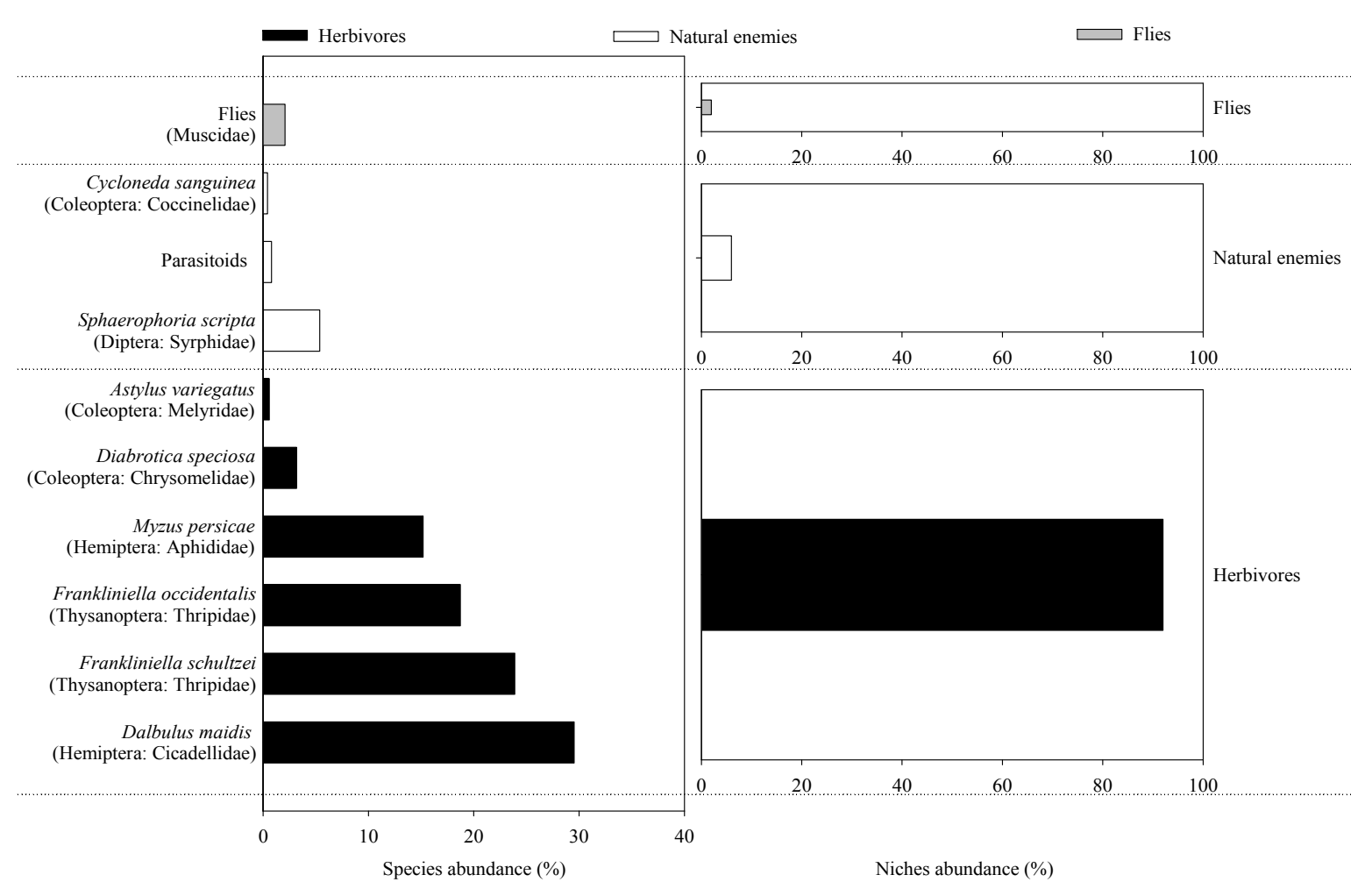

Figure 1. Abundance (\%) of species and niches of herbivores, natural enemies and flies collected through yellow sticky traps, during the pre-flowering period of the industrial tomato, in three production areas of southeast Goiás state, Brazil. Flies were that group of insects of the order Diptera, Muscidae family, with no direct impact on agriculture

The chewing herbivores Diabrotica speciosa (Coleoptera: Chrysomelidae) and Astylus variegatus (Coleoptera: Melyridae) had an abundance of 3.17 and $0.59 \%$, respectively (Figure 1). The predatory fly Sphaerophoria scripta (Diptera: Syrphidae) was the most abundant natural enemy (5.39\%) (Figure 1). Parasitoids (represented by families Ichneumonidae, Trichogrammatidae, Pteromalidae, and Braconidae) added only $0.81 \%$ of the abundance. The ladybird Cycloneda sanguinea (Coleoptera: Coccinelidae), only, $0.42 \%$. Species of Muscidae family flies represented $2.09 \%$ of the insect abundance, independently of the treatments (Figure 1).

Our collections pointed to a larger population of herbivorous insects than natural enemies (Figure 1). This may have been due to the dispersion of these herbivores (mainly suckers) through flights above industrial tomato plants, which facilitates traps visualization. According to Gencsoylu (2007), adhesive traps installed at higher levels in relation to cotton plants also yielded higher numbers of Frankliniella spp. thrips. The height of adhesive trapping, compared to the soil surface, interferes capture of vector insects, such as thrips (MacIntyre-Allen et al., 2005). In addition, the lowest abundance of natural enemies may have been due to the collection period (traps kept in the field up to 60 DAT, days after transplanting). A higher number of natural enemies were observed only starting 80 DAT in organic and conventional tomato systems (Medeiros et al., 2009). Studies of insect sampling in diversified agricultural plantations also indicated a greater number of herbivores in proportion to natural enemies, as reported here. However, larger numbers of natural enemies were observed at the border (vegetation border contaminated with weeds, for example) of tomato crops (Morandi et al., 2014). This reinforces the idea that on a larger scale (for example, beyond the interior of tomato crop where traps were installed) predators and parasitoids may be present more abundant.

A total of 994.25 insects was captured when the tomato was grown with adjacent polyculture (T3) during the experimental period. This value decreased to 569 insects on T2 (tomato with sweet corn) and increased to 771.50 insects on T1 (isolated tomato) $(P=0.02)$ (Figure 2). These results indicate sweet corn was able to retain insects avoiding its colonization in tomato plants. From the perspective of cultural pest control these results are important, since the three main virus transmitters sampled (F. schultzei, F. occidentalis, and M. persicae) had a reduced population in tomato-sweet corn cultivation type (T2). 


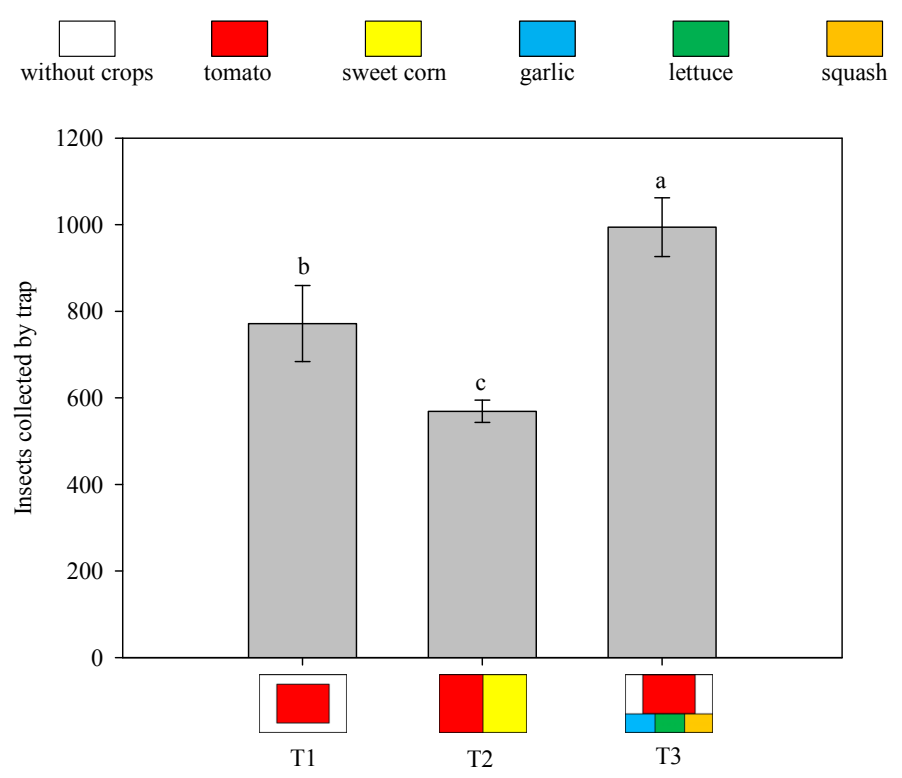

Figure 2. Number of insects (mean $\pm \mathrm{SE}^{1}$ ) collected by yellow sticky traps in three industrial tomato production areas of southeast Goiás state, Brazil. T1 (isolated tomato plants), T2 (tomato plants with sweet corn in the border) and T3 (tomato plants with polyculture in the border). The representation of the agricultural landscape of the three studied areas was defined, by way of illustration, by colored boxes. ${ }^{1}$ Means followed by the same letter in the bars between treatments do not differ at $5 \%$ probability level of Duncan test

The average amount of Frankliniella schultzei thrips collected from traps did not differ in areas with isolated tomato (T1) and tomato with polyculture (T3), yielding traps with 239 and 222.25 insects, respectively (Figure $3 \mathrm{~A})$. In the tomato area with sweet corn (T2), the $F$. schultzei collected average was much lower, corresponding to 97 individuals per trap $(P=0.01)$ (Figure 3A). For Frankliniella occidentalis thrips the area with tomato and polyculture (T3) represented a larger number of collections (195.25 insects), compared to areas with isolated tomato (129.50 insects) or tomato with sweet corn (113.50) $(P=0.01)$ (Figure 3B). Dalbulus maidis was more collected in the tomato area bordered by polyculture (T3), with a mean of 291.50 insects per trap compared to the area of tomato with sweet corn (T2) (190.50) or isolated tomato (T1) (208.25) $(P=0.006)$ (Figure 3C). Myzus persicae was also more captured in tomato with adjacent polyculture (T3), totaling 186 aphids captured per trap (Figure 3D). The cultivation of isolated industrial tomatoes provided the second largest number of aphids collected (128.25) and tomato kept with sweet corn (T2) influenced the capture of a smaller number of aphids $(41,50)$ (Figure 3D). 


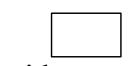

without crops
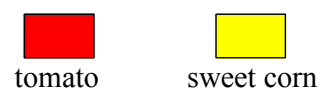

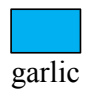

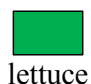

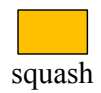

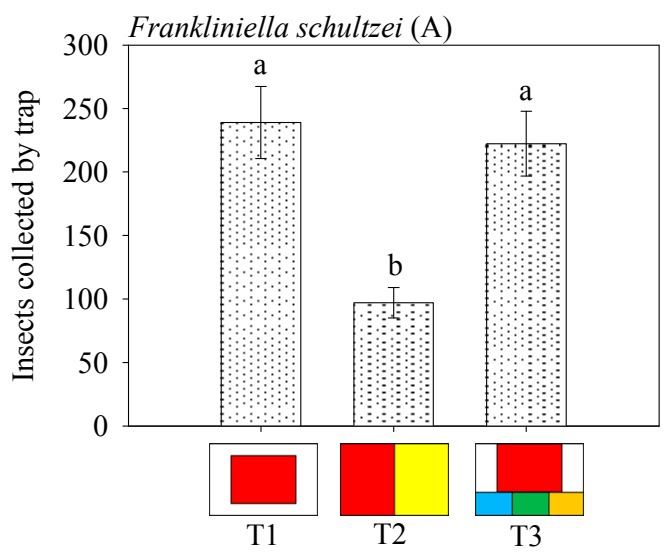
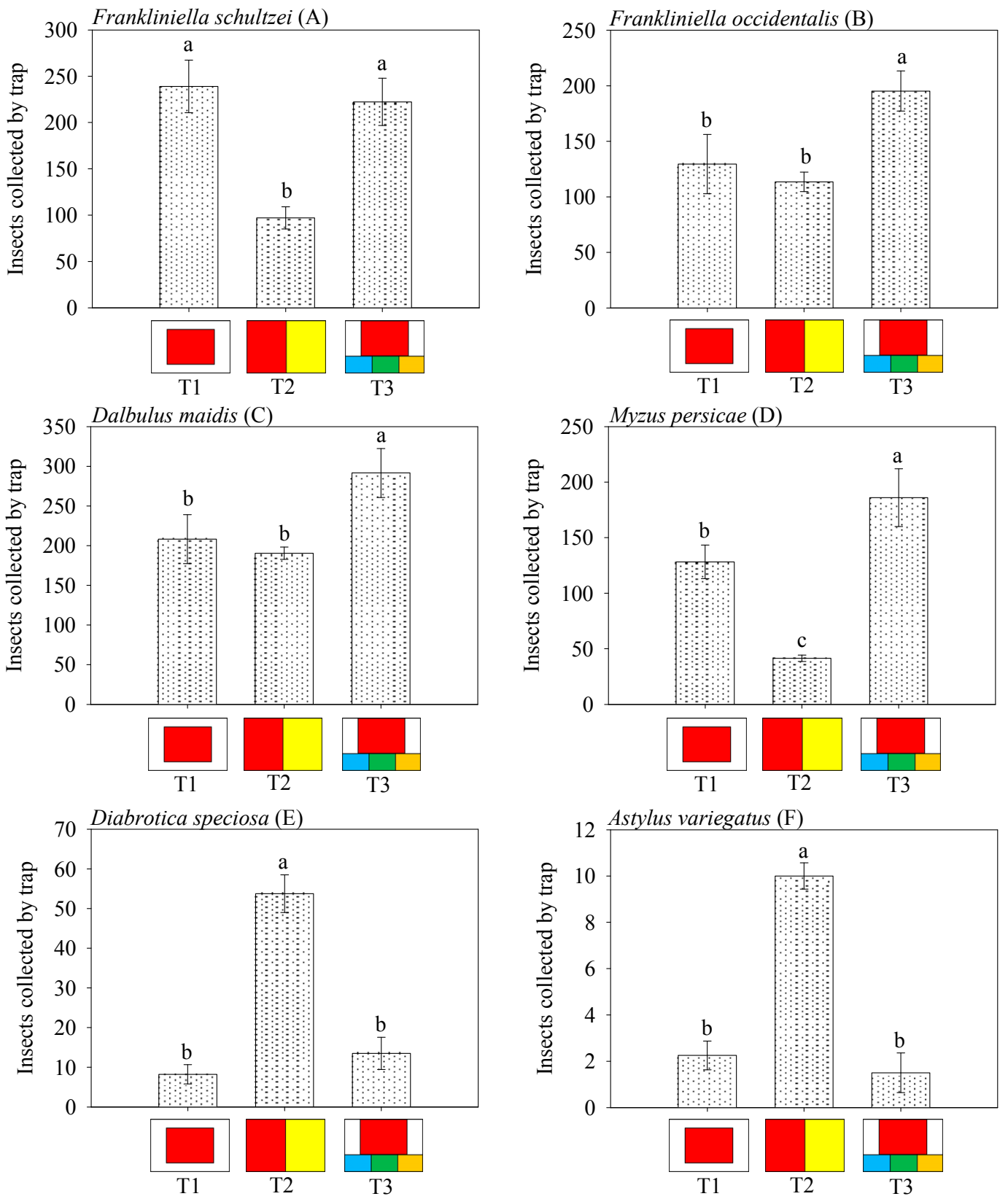

Figure 3. Number of herbivores (Mean $\pm \mathrm{EP}^{1}$ ), by species (Figures 3A to 3F), collected by yellow sticky traps in three areas of industrial tomato production of southeast Goiás state, Brazil. T1 (isolated tomato plants), T2

(tomato plants with sweet corn in the border) and T3 (tomato plants with polyculture in the border). The representation of the agricultural landscape of the three studied areas was defined, by way of illustration, by colored boxes. ${ }^{1}$ Means followed by the same letter in the bars between treatments do not differ at $5 \%$ probability level of Duncan test

The polyculture system (tomato + garlic + lettuce + squash) has not been shown to be advantageous in limiting the presence of sucking insects in tomato plants. Lettuce, garlic and squash plants may have served as reservoirs for the two species of thrips found. The dispersion of insects in agricultural systems is strongly related to behavioral traits (Mazzi \& Dorn, 2012). According to Mound (2003), Thysanoptera individuals may be present in plants that are not necessarily their natural hosts due, for example, to shelter. This reinforces the argument that polyculture may have served as a reservoir. The smaller number of corn leafhoppers in T2 may have been due to 
the presence of this insect in sweet corn plants, its natural host (Oliveira et al., 2007). Garlic, lettuce, and squash are not hosts of the corn leafhopper. Thus, individuals of D. maidis may have arisen from areas bordering T3, reinforcing their recognized dispersal ability (Meneses et al., 2016). The green leafhopper (Empoasca spp.) which also transmits virus species to tomato plants (Lourdes et al., 1986) belongs to the same taxonomic family (Cicadellidae) as the corn leafhopper. Thus, the presence of D. maidis in tomato plants should be conveniently investigated to know the real role of this insect, as (or not) possible vector of viruses.

The capture pattern of the chewing herbivores Diabrotica speciosa and Astylus variegatus was similar, with T3 giving rise to a larger number of individuals collected (for $D$. speciosa: $P=0.002$ and for $A$. variegatus: $P=$ 0.000 ) (Figures 3E and 3F). However, the mean number of $D$. speciosa individuals captured (T1: 8.25, T2: 53.75 and T3: 13.50) was much higher than A. variegatus (T1: 2.25, T2: 10, 00 and T3: 1.50) for each treatment (Figures 3E and 3F). The largest population of Diabrotica compared to Astylus, in all three treatments, points out that Chrysomelidae is one of the main leaf chewing insects of Solanaceae seedlings. High incidences of $D$. speciosa have been reported frequently in Goiás state. The ecological and behavioral reasons for this fact should be properly investigated. As both beetles are also pests in sweet corn, the ability of this plant to serve as companion for tomato plants was not equally observed, as in the case of the two thrips and the aphid species.

Cycloneda sanguinea predators, in spite of the low abundance, were more captured in tomato cultivated with polyculture in the border (T3) $(P=0.000)$ with a mean of 6.25 individuals per trap (Figure 4A). Tomato planting with sweet corn (T2) provided the lowest mean number of ladybugs captured in the experiment $(0.75)$ compared to isolated tomato planting (3.50 individuals per trap) (Figure 4A). The number of parasitoids per trap, in descending order of collections, was 11.50 (T3), 4.25 (T2) and $4.00(\mathrm{~T} 1)(P=0.007)$ (Figure 4B). The predatory fly Sphaerophoria scripta was more collected in areas of industrial tomato surrounded by polyculture (48.25 individuals per trap) and sweet corn (46.75 individuals per trap) compared to the isolated tomato area (32.75) $(P$ $=0.04$ ) (Figure 4C). The number of $S$. scripta predatory flies captured was higher than other natural enemies, and corresponded to 12.6 times the number of ladybugs captured and 6.63 times the number of captured parasitoids. Finally, the number of flies (Muscidae family) did not differ between treatments $(P>0.05)$ (Figure 4D), with a mean of 16.41 flies captured per trap. Some specialist natural enemies (for example, parasitoids) are more sensitive to environmental disturbances, such as system simplification (Gámez-Virués et al., 2015). Sphaerophoria scripta are predators of immature sucking insects and small caterpillars in agricultural plantations, as in corn (Krawczyk et al., 2011). This justifies their greater presence only in T2 and T3 compared to T1. 


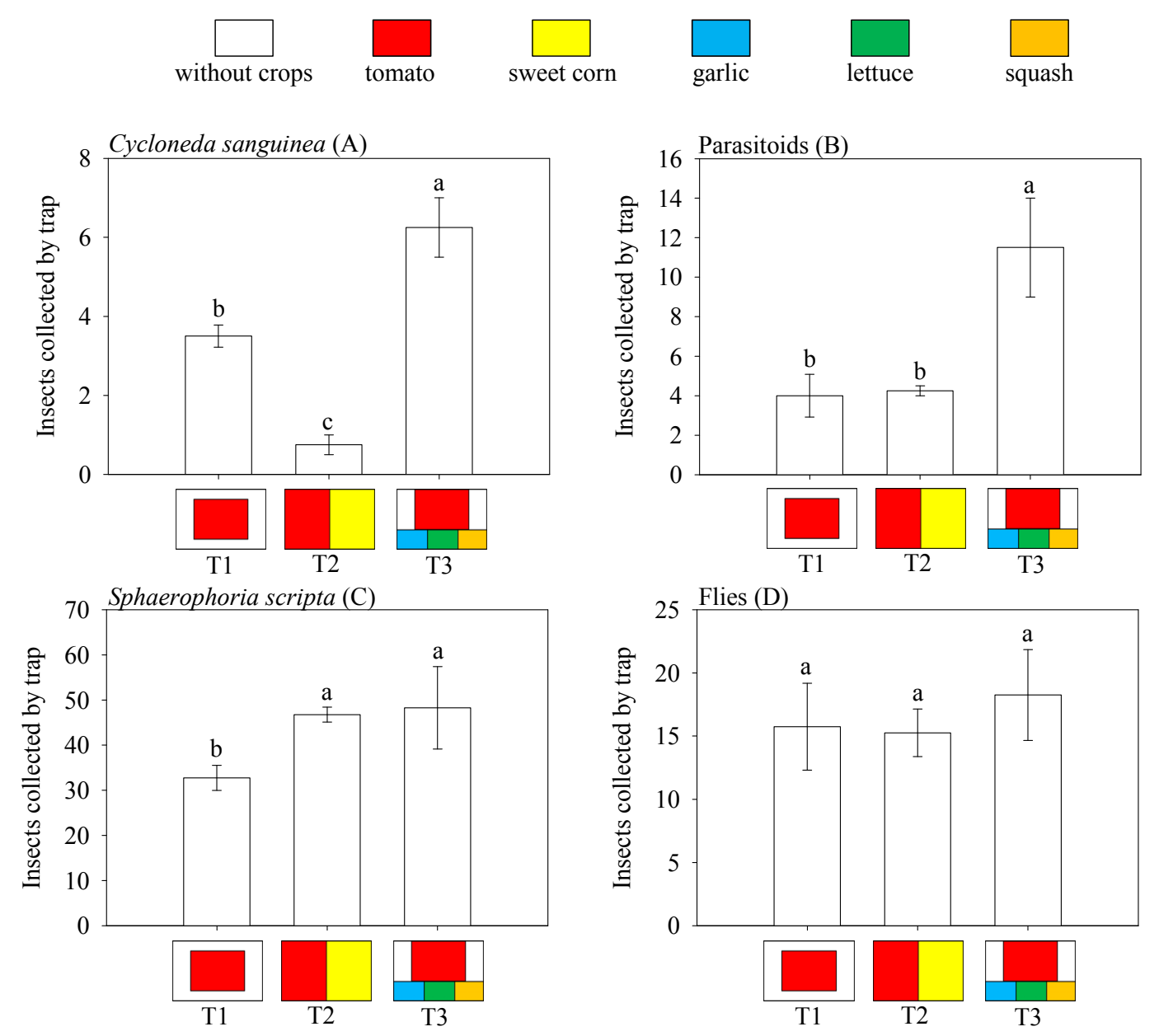

Figure 4. Number of natural enemies (Mean $\pm \mathrm{EP}^{1}$ ) by species (Figures $4 \mathrm{~A}$ and $4 \mathrm{C}$ ) and by groups (Figures 4B and 4D) collected by yellow sticky traps in three industrial tomato production areas of southeast Goiás state, Brazil. T1 (isolated tomato plants), T2 (tomato plants with sweet corn in the border) and T3 (tomato plants with polyculture in the border). The representation of the agricultural landscape of the three studied areas was defined, by way of illustration, by colored boxes. ${ }^{1}$ Means followed by the same letter in the bars between treatments do not differ at $5 \%$ probability level of Duncan test

Sweet corn served as a companion plant to industrial tomato plants, especially for thrips and aphids. This indicates the hypothesis of the present study was accepted. Perhaps sweet corn is somehow hindering host location of these virus vectors insect groups. Agricultural landscape diversification brings with it the advantage of the support capacity of a larger number of individuals. That is, more insects were collected in this type of agricultural system, as observed in T3 (Figure 2). The high values of insects in T1 should be interpreted with caution, due to the large presence of corn leafhoppers collected leading to a possible biased overestimation. Such implications suggest that the complexity of agricultural landscape increases in quantity the diversity of species in the system. However, interpretations regarding the advantages of this cultural practice cannot be generalized and therefore must consider the importance that each insect sampled plays in the industrial tomato agricultural system.

\section{Conclusions}

The environmental complexity built at the present study favored insect diversity in industrial tomato fields. Sucking insects were abundant in the tomato pre-flowering stage. Sweet corn served as a companion plant for tomato, likely in the sense of hampering access of thrips and aphids to this Solanaceae. However, the same behavioral pattern was not observed for chewing beetles, because tomato plants cultivated next to sweet corn were the ones with high incidences. Larger populations of natural enemies were collected in T3, which agrees with theories about maintenance and increase of biodiversity in agricultural systems. Ladybugs and parasitoids were scarcer in the tomato-corn treatment (T2). The predator Sphaerophoria scripta was the only natural enemy 
that was remarkably abundant and favored by environmental diversity, been benefited by the context of sweet corn as a companion plant to industrial tomato plants.

\section{Acknowledgements}

To Mr. Alexandre Lutkemeyer (In memoriam) and Mrs. Fernanda de Souza Ferreira that allowed part of the experiment was realized in their tomato production area. To CNPq for the granting of financial assistance. The Foundation for Research Support of the state of Goiás (FAPEG). To the PAPPE Program of the Instituto Federal Goiano that granted a research grant to Alexandre IA Pereira (Process n ${ }^{\circ}$ 23216.000570/2017-26). And, finally, to Instituto Federal Goiano for the structural support for the execution of this work.

\section{References}

Baideng, E. L., Memah, V., \& Tallei, T. E. (2017). Monitoring of species and population of important insect pest of tomato plants using yellow sticky trap during conventional and integrated pest management system. Journal of Animal \& Plant Sciences, 34, 5404-5412. https://doi.org/10.1007/s10526-008-9164-y

Barbosa, V. S., Leal, I. R., Iannuzzi, L., \& Almeida-Cortez, J. (2005). Distribution pattern of herbivorous insects in a remnant of Brazilian Atlantic Forest. Neotropical Entomology, 34, 701-711. https://doi.org/10.1590/S15 19-566X2005000500001

Carvalho, J. L., \& Pagliuca, L. G. (2007). Tomate, Um Mercado Que Não Para De Crescer Globalmente. Hortifruti Brasil, 6, 6-14.

Degri, M. M., \& Samaila, A. E. (2014). Impact of intercropping tomato and maize on the infestation of tomato fruit borer [Helicoverpa armigera (Hubner)]. Journal of Agricultural and Crop Research, 2, 160-164.

Gámez-Virués, S., Perović, D. J., Gossner, M. M., Börschig, C., Blüthgen, N., de Jong, H., ... Westphal, C. (2015). Landscape simplification filters species traits and drives biotic homogenization. Nature Communications, 6, 8568. https://doi.org/10.1038/ncomms9568

Gencsoylu, I. (2007). Evaluation of yellow sticky traps on populations of some cotton pests. American-Eurasian Journal of Agricultural and Environmental Sciences, 2, 62-67.

Gotelli, N. J., \& Ellison, A. M. (Eds.). (2011). Princípios de estatística em ecologia. Porto Alegre, RS: Artmed.

IBGE (Instituto Brasileiro De Geografia E Estatística). (2015). Sidra-Banco De Dados Agricultura. Retrieved From http://www.Sidra.Ibge.Gov.Br

Krawczyk, A., Hurej, M., \& Jackowski, J. (2011). Syrphids and their parasitoids from maize crop. Journal of Plant Protection Research, 51, 93-97. https://doi.org/10.2478/v10045-011-0017-9

Lima, I. P., Resende, J. T. V., Oliveira, J. R. F., Faria, M. V., Dias, D. M., \& Resende, N. C. V. (2016). Selection of tomato genotypes for processing with high zingiberene content, resistant to pests. Horticultura Brasileira, 34, 387-391. https://doi.org/10.1590/S0102-05362016003013

Lourdes, M., Borges, V., \& Sequeira, J. C. (1986). Viruses recorded in Portugal in tomato protected crops. Acta Horticulturae, 191, 293-302. https://doi.org/10.17660/ActaHortic.1986.191.33

Macintyre-Allen, J. K., Scott-Dupree, C. D., Tolman, J. H., \& Harris, C. R. (2005). Evaluation of sampling methodology for determining the population dynamics of onion thrips (Thysanoptera: Thripidae) in Ontario onion fields. Journal of Economic Entomology, 98, 2272-2281. https://doi.org/10.1603/0022-0493-98.6. 2272

Meneses, A. R., Querino, R. B., Oliveira, C. M., Maia, A. H. N., \& Silva, P. R. R. (2016). Seasonal and vertical distribution of Dalbulus maidis (Hemiptera: Cicadellidae) in Brazilian corn fields. Florida Entomologist, 99, 750-754. https://doi.org/10.1653/024.099.0428

Miranda, M. M. M., Picanço, M., Leite, G. L. D., Zanuncio, J. C., \& De Clercq, P. (1998). Sampling and non-action levels for predators and parasitoids of virus vectors and leaf miners of tomato plants in Brazil. Mededelingen Faculteit Landbouwwetenschappen Rijksuniversiteit Gent, 63, 519-523.

Morandi, L. A., Long, R. F., \& Kremer, C. (2014). Hedgerows enhance beneficial insects on adjacent tomato fields in an intensive agricultural landscape. Agriculture, Ecosystems and Environment, 189, 164-170. https://doi.org/10.1016/j.agee.2014.03.030

Mound, L. (2003). Thysanoptera. In V. H. Resh, \& R. T. Cardé (Eds.), Encyclopedia of insects (Vol. 2, pp. 1127-1132). Berkeley, California: Academic Press. 
Moura, A. P., Michereff Filho, M., Guimarães, J. Á., \& Liz, R. S. (Eds.). (2014). Manejo integrado de pragas do tomateiro para processamento industrial. Brasília, DF: Embrapa Circular Técnica.

Njuguna, E., Gathara, M., Nadir, S., Mwalusepo, S., Williamson, D., Mathé, P. E., ... Calatayud, P. A. (2015). Characteristics of soils in selected maize growing sites along altitudinal gradients in East African highlands. Journal Data in Brief, 5, 138-144. https://doi.org/10.1016/j.dib.2015.08.030

Oliveira, C. M., Oliveira, E., Canuto, M., \& Cruz, I. (2007). Controle químico da cigarrinha-do-milho e incidência dos enfezamentos causados por molicutes. Pesquisa Agropecuária Brasileira, 42, 297-303. https://doi.org/10.1590/S0100-204X2007000300001

Palisade Corporation. (2002). @RISK-Risk Analysis and Simulation Add-In for Microsoft Excel. Newfield, USA.

Ratnadass, A., Fernandes, P., Avelino, J., \& Habib, R. (2012). Plant species diversity for sustainable management of crop pests and diseases in agroecosystems: A review. Agronomy for Sustainable Development, 32, 273-303. https://doi.org/10.1007/s13593-011-0022-4

Silva, J. D., Giordano, L. D. B., Furumoto, O., Boiteux, L. D. S., França, F. H., Villas-Boas, G. L. V., \& Ávila, A. C. (2003). Cultivo De Tomate Para Industrialização. Brasília, Df: Embrapa Hortaliças.

Wallerberger, M., \& Gull, E. (2017). Hypothesis testing of scientific Monte Carlo calculations. Physical Review, 96, 053303. https://doi.org/10.1103/PhysRevE.96.053303

Yen, A. L., Madge, D. G., Berry, N. A., \& Yen, J. D. L. (2013). Evaluating the effectiveness of five sampling methods for detection of the tomato potato psyllid, Bactericera cockerelli (Šulc) (Hemiptera: Psylloidea: Triozidae). Austral Entomology, 52, 168-174. https://doi.org/10.1111/aen.12006

\section{Copyrights}

Copyright for this article is retained by the author(s), with first publication rights granted to the journal.

This is an open-access article distributed under the terms and conditions of the Creative Commons Attribution license (http://creativecommons.org/licenses/by/4.0/). 